\title{
The Level of Climate Change Awareness among Citizens of Bitung City, Indonesia
}

\author{
Syamsudin Nggole ${ }^{1}$ \\ Badan Perencanaan dan Pembangunan Daerah Kota Bitung, Bitung, Indonesia
}

\section{Wido Prananing Tyas}

Departemen Perencanaan Wilayah dan Kota, Universitas Diponegoro, Semarang, Indonesia

\author{
Wisnu Pradoto \\ Departemen Perencanaan Wilayah dan Kota, Universitas Diponegoro, Semarang, Indonesia
}

Artikel Masuk : 4 September 2018

Artikel Diterima : 11 Februari 2019

Tersedia Online : 30 April 2019

\begin{abstract}
Knowledge about citizen's climate change awareness level is needed to establish an appropriate policy to cope with climate change hazard, particularly in a highly vulnerable country like Indonesia. However, research regarding climate change awareness among citizens in Indonesian cities is limited. This research aims to investigate the level of climate change awareness among the citizens in Bitung City, a medium-sized city in the eastern part of Indonesia. The survey method is used in the research by analyzing questionnaires collected from the citizens. Three variables for measuring the awareness level include public concerns on climate variability, the causes of climate change, and the impacts of climate change. The findings show that the citizens of Bitung have a "quite strong" awareness level. This contributes to the recognition of citizens' characteristics toward climate change useful to climate change policy formulation in Indonesia, particularly the Bitung City Government. Some recommendations for the government include the incorporation of climate change issue to the citizens' daily life and development programs by establishing a special task force of climate change at the city level.
\end{abstract}

Keywords: awareness level; Bitung City; citizens; climate change

\section{Introduction}

Climate change is perceived as one of the most significant challenges we are currently facing in our world today (Madumere, 2016) since it has affected the living place and the livelihood of the world inhabitants. United Nations Framework Convention on Climate Change (UNFCCC), as cited in Ghoneem (2016), defines climate change as a change of climate that is attributed directly or indirectly to human activity that alters the composition of the global atmosphere, and that is in addition to natural climate variability observed over comparable periods. Since the impacts of climate change are experienced locally, countries all over the world are forced to address climate change issue into their

\footnotetext{
1 Korespondensi Penulis: Badan Perencanaan dan Pembangunan Daerah Kota Bitung, Bitung, Indonesia email: syamsudinnggole@gmail.com
} 
planning and development strategies (Ghoneem, 2016). However, many governments, particularly in the developing countries, are lacking of concern in prioritizing policies to tackle climate change even though they have experienced and been vulnerable to disasters caused by climate change such as flood, drought, forest fire, and excessive increase of temperature (Dale et al., 2001; Ghoneem, 2016; Ghozali et al., 2016; Zamasiya et al., 2017).

Indonesia is known as one of the developing countries that prone to climate change impacts. World Bank ranks Indonesia as the $12^{\text {th }}$ out of thirty-five countries facing a relatively high mortality risk from multiple hazards, including from climate change impacts (World Bank, 2011). In contrast, Indonesia is at the top five of the contributing countries to the greenhouse gases (GHGs) emission (Chrysolite et al., 2017). Regarding the nationally determined contribution (NDC) released in 2016, the Government of Indonesia has committed to reducing GHG emission by 29 per cent against a 2030 business-as-usual (BAU) scenario, and by up to 41 per cent below the 2030 BAU level, subject to assistance from the international forum for finance, technology transfer, and capacity building (Wijaya et al., 2017). Many policies have been established by the government to tackle the climate change such as National Action Plan Addressing Climate Change 2007, Indonesia Climate Change Sectoral Road Map 2010, and National Action Plan for Climate Change Adaptation 2014 (Ministry of Environment and Forestry, 2016). However, according to Gallup World Poll 2007-2008, Indonesian citizens were categorized as having low awareness on climate change issue (Lee et al., 2015). This could be considered as the main impediment for the success of climate change policies in Indonesia.

Patchen (2006) argues that some people show their concern about climate change, while many others have not. Those who perceive climate change is still far away, or those who think of that climate change will not have any impacts to them will put little concern and tend to be apathetic to this issue (Lieske et al., 2014; Singh et al., 2017). Moreover, those who show their concern believe that the world's climate is changing (Hayles \& Dean, 2015 ) and aware of its causes and impacts. As found by Rao (2011) in Hyderabad, India, a majority of people (60-65\%) point out an increase in temperature, long summers, increasing humidity, fluctuating temperatures, erratic seasons, extreme weather, less rain, dry spells, and shorter winter. Moreover, farmers in Malaysia have expressed their concern on climate variability, such as rising temperature, changing rainfall pattern, and increasing drought (Masud et al., 2017).

Although global climate change has received a consensus among global citizens, however, there is still a variability of knowledge concerning its causes. While the public Americans agree that the earth is getting warmer, it is only about $41 \%$ people have perceived that human activity, such as fossil fuel burning, causes global warming (Patchen, 2006). Moreover, in Hyderabad, understanding the causes of global warming is limited, where $23.5 \%$ people consider that global warming is not caused by vehicle emissions, deforestation, or industrial pollution (Rao, 2011). IPCC (2007), as cited in Holdren (2008), has released the primary source of GHG emissions that cause climate change. The burning of fossil fuel dominates the GHG emission source through the form of energy supply $(25.9 \%)$, industrial activity (19.4\%), and transport (13.1\%). Waste contributes $2.8 \%$ of the GHG emission regarding the fact that many developing countries are still adopting landfill method in waste management system even though it has adverse effects to the environment through methane production released to the atmosphere (Malik, Abdullah, \& Manaf, 2015). Moreover, a reduction in food losses and waste at global, regional, and national levels will have a substantial positive effect on climate change (FAO, 2011).

In general, people also concern about the impacts of climate change and perceive it as a severe problem to the earth future (Hayles \& Dean, 2015; Lieske et al., 2014). Farmers in Zimbabwe note that since 2000 the frequency of drought increases, thus, affects agricultural crop productivity by altering temperature and water availability at critical stages of crop growth (Zamasiya et al., 2017). On the contrary, people and government $f$ 
Samarinda City, Indonesia, and Ayutthaya, Thailand are struggling with the annual flood risk that they believe increasing due to the emerging climate change (Ghozali et al., 2016).

Considering the implementation of climate change policies aforementioned, it is crucial to investigate how the current level of climate change awareness among Indonesian citizens. However, the research on climate change awareness in Indonesian cities is limited so that this study result is needed to establish appropriate climate change policies based on citizens' characteristics toward climate change. This research aims to investigate the level of climate change awareness among the citizens in Bitung City, a medium-sized city in the eastern part of Indonesia. Findings from this research could be used as the foundation for establishing climate change policy at the city level.

\section{Methods}

\section{Research Location}

This research survey was conducted in Bitung City, North Sulawesi Province of Indonesia (Figure 1). The Central Board of Statistics of Bitung City (2015) recorded that the city is one of the fastest-growing economies in Indonesia with the presence of international seaport and exclusive economic zone of fisheries, plantation, and pharmaceutical industries. Hence, it contributed to the high rate of population growth. Moreover, the city becomes susceptible to the climate change since 43 out of 69 urban villages are located at the coast of the Celebes Sea and Moluccas Sea (Central Board of Statistics of Bitung City, 2015). Moreover, the topography of the city that dominated with hilly type and its land coverage that dominated by conservation forest area (Central Board of Statistics of Bitung City, 2015) make the city more vulnerable to climate change effect.

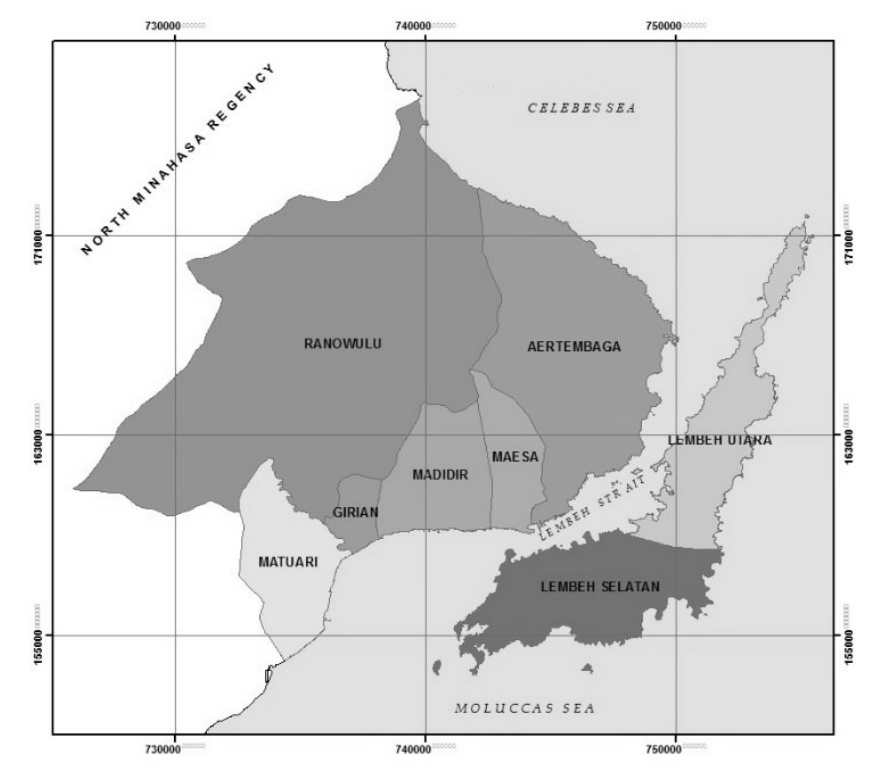

Source: Public Works Agency of North Sulawesi, 2014

\section{Figure 1. Bitung City Map}

Regarding the demographic facts in 2015, the citizens of Bitung are mostly welleducated as $49 \%$ population finished their secondary education, where $12 \%$ of them continued to tertiary education. It is only $8.2 \%$ did not complete their primary school and $0.1 \%$ not attending the school(Central Board of Statistics of Bitung City, 2016). Moreover, 


\section{The Level of Climate Change Awareness among Citizens of Bitung City, Indonesia}

almost $60 \%$ of the labor force in Bitung have an occupation that related to the industry, fisheries, and service and tourism as these factors determine as the development priority of the city. Of this occupations figure, $24 \%$ of the labor force work as a private employee in the service and tourism sector, $19 \%$ as fishermen, and $15 \%$ as labor in the industrial sector. The rest $40 \%$ are distributed as a farmer $(14 \%)$, government officer $(8 \%)$, entrepreneur $(4 \%)$, military force and police $(2 \%)$ and others (15\%).

Concerning the city infrastructure, clean water provision for the citizens served by Perusahaan Daerah Air Minum (PDAM - the Local Drinking Water Company) using spring water and chemical processed river water. However, it serves only $65 \%$ of the household population, while the remaining are using deep groundwater to meet their need for clean water (Mananoma et al., 2010). Electricity provision served by Perusahaan Listrik Negara (PLN - the State-Owned Electricity Company) using diesel power plant and supported by Minahasa geothermal and hydropower plant interconnection system (Labulu et al., 2015). However, as there are many big-scale industries in Bitung, their electricity supply is generated from their own generator set fuelled by diesel and coal (Central Board of Statistics of Bitung City, 2016). Public transport provision is operated by private companies using fossil-fueled vehicles, namely minibus, car, boat, and motorbike. The Local Environmental Agency is responsible for wasting management by collecting it from the waste producers and then dumping it to the city sanitary landfill. The agency initiated 3R (reduce, reuse, and recycle) and waste bank policy to minimize the waste heat in the sanitary landfill. Moreover, to support these policies, the agency provides three colors of a waste bin for organic, non-organic, and hazardous waste (Malee et al., 2016)

\section{Research Strategy}

The survey method was adopted as the research strategy to address the aim of the research. The survey method was chosen because it can cover a large population and it is a representative selection from the population of a particular type (Biggam, 2015; Masud et al., 2017) since this research is located in Bitung City, a medium city with significant population growth in Indonesia. The data obtained by distributing questionnaires to the respondents living in the eight districts of Bitung City in accordance with the prior sampling calculation. The questionnaires distribution and collection process conducted in three weeks from November to December 2017. The questionnaire presented in the Indonesian language. It consisted of 11 statements which were divided into three main themes according to the determined variables concerning climate's variability (two statements), concern about the climate change causes (four statements), and concern about the climate change impacts (five statements). Respondents indicated their responses into a 4-point Likert scale. This statement asked for a degree of agreement that ranges from Strongly Disagree (SDS), Disagree (DS), Agree (A), to Strongly Agree (SA).

\section{Population and Sample}

The population unit in this research is the household with the assumption that the actions to tackle climate change mostly originated from the households (Elrick-Barr et al., 2016; Masud et al., 2017; Zamasiya et al., 2017). The number of households used in this research was 54.802 households according to the data obtained from the Central Board of Statistics of Bitung City in 2015 (Central Board of Statistics of Bitung City, 2016). The Slovin's formula was conducted to obtain a suitable sample size from this population. This formula is used because the number of population is known, and all of the population has an equal opportunity to be respondent (Dhokhikah et al., 2015; Masud et al., 2017). For the accuracy of the research, the error margin determined $5 \%$. Thus, the sample formula was shown in equation (1), where $\mathrm{n}$ is a number of the sample; $\mathrm{N}$ is a total population, and $\mathrm{d}$ is an error margin (0.05). The formula results in a sample size of 397 respondents. 


$$
n=\frac{N}{(N x d 2)}+1
$$

\section{Data Analysis}

The analysis method used quantitative analytical approach, namely scoring and descriptive statistics methods. Scoring analysis used to weight the statement's responses of each variable. A score of 1, 2, 3 and 4 was given for "Strongly Disagree," "Disagree," "Agree," and "Strongly Agree" respectively. The total score of responses in each variable then converted to the percentage value of awareness level by comparing the total score with a maximum score that can be achieved in every variable shown in the equation (2).

$$
\text { Awareness Level }=\left(\frac{S v}{S m}\right) \times 100 \%
$$

Sv is a total score of variable and $\mathrm{Sm}$ is a maximum score of a variable. The statistical results then interpreted by giving description as follows:

Weak $\quad=25.00 \% \leq$ Awareness Level $\leq 43.75 \%$

Quite Weak $=43.75 \%<$ Awareness Level $\leq 62.50 \%$

Quite Strong $=62.50 \%<$ Awareness Level $\leq 81.25 \%$

Strong $\quad=81.25 \%<$ Awareness Level $\leq 100.00 \%$

\section{Results and Discussion}

\section{Characteristics of the Respondents}

A total of 460 questionnaires distributed to the respondents in Bitung City. From that number, a total of 429 questionnaires were returned and checked for completeness before data entry started. After checking process, a total of 423 questionnaires were completed, exceeded the sample 397 questionnaires that were expected according to the formula (1). To have a more accurate result, the 423 questionnaires then counted into the data entry. The gender composition of the respondents were female (53\%) and male (47\%). Regarding their age distribution, the respondents were dominated by those at the age interval of 31 to 45 years old $(52 \%)$, followed by 46 to 60 years old $(26 \%), 17$ to 30 years old $(20 \%)$, and above 60 years old $(2 \%)$. Most of the respondents finished their senior high school education level $(51 \%)$ or above $(29 \%)$ while those who finished junior high school or lower education level was 20\%. Moreover, there was $21 \%$ respondents working as the government official or military force or police officer while the remaining had their own business or entrepreneur $(16 \%)$, employee in the private sector $(12 \%)$, factory labor $(4 \%)$, fishermen or farmers $(7 \%)$ or others including housewife and unemployed $(40 \%)$. The majority of the respondents had an income of IDR 2,000,000 or below (54\%) which is the minimum standard of living in Bitung, others were between IDR 2,000,000 to IDR $6,000,000(42 \%)$, and the remaining $4 \%$ were above IDR 6,000,000.

\section{Concern about Climate's Variability}

Regarding the climate change, the Local Climatology Agency in Bitung has recorded that there was a change in monthly and seasonal rainfall pattern that indicated a shift in initial time and duration of dry and rainy seasons in Bitung (Bitung's Maritime Station of Meteorological Climatology and Geophysics, 2017). Table 1 shows the monthly and seasonal rainfall pattern during the last ten years (2007-2016). The table shows a number of changes in the monthly average rainfall. There are months in the dry season (AprilSeptember) with a high and very high rainfall, i.e., July 2008, April, June and July 2010 
which indicated a long duration of the rainy season. On the contrary, there are months in the rainy season with a low average of rainfall, i.e., February 2007-2010 and 2014, which indicated a shift in the dry season's initial time.

Besides, there is an indication of a prolonged drought that occurred in 2014 showed by the low rainfall value from September to December 2014. This year also showed the lowest annual average rainfall in the ten years. A prolonged drought was also indicated in 2016 where the highest monthly average rainfall occurred in June and July was only 200 $\mathrm{mm} / \mathrm{month}$ while the remaining months were less than $200 \mathrm{~mm}$ and $100 \mathrm{~mm}$ per month.

Table 1. Monthly and Annual Rainfall Pattern in Bitung (2007-2016)

\begin{tabular}{lcccccccccc}
\hline \multirow{1}{*}{ Month } & \multicolumn{10}{c}{ Year } \\
\cline { 2 - 8 } & $\mathbf{2 0 0 7}$ & $\mathbf{2 0 0 8}$ & $\mathbf{2 0 0 9}$ & $\mathbf{2 0 1 0}$ & $\mathbf{2 0 1 1}$ & $\mathbf{2 0 1 2}$ & $\mathbf{2 0 1 3}$ & $\mathbf{2 0 1 4}$ & $\mathbf{2 0 1 5}$ & $\mathbf{2 0 1 6}$ \\
\hline January & 166.2 & 285.5 & 98.6 & 104.5 & 155.1 & 118.1 & 170.1 & 247 & N/A & 88 \\
February & 39.3 & 87.5 & 85.2 & 87.9 & 296.8 & 141.8 & 326.0 & 89 & N/A & 101 \\
March & 201.3 & 143.8 & 164.8 & 70.4 & 164.1 & 283.3 & 109.0 & 123 & N/A & 30 \\
April & 83.1 & 210 & 113.3 & 429.8 & 234.0 & 159.5 & 274.0 & 136 & N/A & 85 \\
May & 222.2 & 136 & 293.5 & 220.2 & 98.5 & 153.6 & 195.0 & 237 & N/A & 119 \\
June & 191.5 & 237 & 183.9 & 409.7 & 208.5 & 105.4 & 133.2 & 157 & N/A & 221 \\
July & 241.9 & 331.1 & 66.4 & 352.8 & 13.7 & 151.5 & 209.0 & 46 & N/A & 210 \\
August & 100.6 & 219.3 & 21.7 & 183.8 & 40.2 & 41.0 & 109.7 & 120 & N/A & 88 \\
September & 19.1 & 89.2 & 5.0 & 252.0 & 129.3 & 25.0 & 55.0 & 1 & N/A & 105 \\
October & 55.4 & 159.3 & 144.4 & 211.6 & 167.2 & 100.1 & 26.0 & 1 & N/A & 128 \\
November & 367.7 & 110 & 312.4 & 209.2 & 205.4 & 221.4 & 123.0 & 68 & N/A & 47 \\
December & 137.7 & 195.8 & 109.8 & 234.3 & 137.7 & 202.9 & 72.0 & 58 & N/A & 163 \\
Average & 152.2 & 183.7 & 133.3 & 230.5 & 154.2 & 141.9 & 150.2 & 106.9 & 127 & 115.4 \\
\hline Note & & & & & & & & & &
\end{tabular}

Notes:

Low: 0-100 mm/month; Medium: 101-300 mm/month; High: 301-400 mm/month; Very High: $>400$ mm/month N/A: Data Not Available

Source: Bitung's Maritime Station of Meteorological, Climatology, and Geophysics Agency, 2017

Table 2 shows the monthly and annual temperature in the last ten years (2007-2016). The mean value of temperature for this period was $27.8^{\circ} \mathrm{C}$. The Local Climatology Agency recorded that for the four consecutive years since 2013, the annual average temperature was above the mean value. Furthermore, the trend was showing an increase of $0.3^{\circ} \mathrm{C}$ in annual temperature for this period (Bitung's Maritime Station of Meteorological Climatology and Geophysics, 2017).

Respondents have been asked for the irregularity of the seasons' initial time in Bitung and the increase of temperature that has made Bitung hotter for the past few years. The result in Table 3 shows a majority of respondents expressing their agreement (31\% strongly agree, and $63 \%$ agree) that the season comes irregularly in Bitung for the past few years. It is only $6 \%$ ( $5 \%$ disagree, and $1 \%$ strongly disagree) of the respondents showed their disagreement on this statement. For the second statement, there is $89 \%$ (33\% strongly agree, and $56 \%$ agree) of respondents agreed upon that temperature in the city is getting hotter since the past few years and $11 \%$ (10\% disagree, and 1\% strongly disagree) stated the opposite answers. Both statements received a high percentage of agreements. However, more citizens showed their "strongly agree" opinions to the increased temperature statement when, at the same also received a higher "disagree" opinions compared with the other statement. 
Table 2. Monthly and Annual Temperature in Bitung (2007-2016)

\begin{tabular}{|c|c|c|c|c|c|c|c|c|c|c|}
\hline \multirow{2}{*}{ Month } & \multicolumn{10}{|c|}{ Year } \\
\hline & 2007 & 2008 & 2009 & 2010 & 2011 & 2012 & 2013 & 2014 & 2015 & 2016 \\
\hline January & 28.3 & 28.2 & 28.3 & 28.1 & 27.7 & 27.8 & 28.2 & 28.3 & 28.4 & 27.9 \\
\hline February & 28.0 & 27.7 & 28.4 & 27.9 & 27.5 & 27.8 & 27.7 & 28.2 & 27.6 & 28.3 \\
\hline March & 27.5 & 27.5 & 27.7 & 28.4 & 27.8 & 27.7 & 28.6 & 28.2 & 28.1 & 28.7 \\
\hline April & 27.2 & 26.3 & 27.4 & 27.4 & 29.3 & 26.8 & 27.1 & 28.4 & 28.4 & 28.8 \\
\hline May & 28.2 & 27.8 & 28.0 & 28.5 & 28.3 & 28.1 & 28.2 & 27.7 & 28.8 & 27.5 \\
\hline June & 27.8 & 27.5 & 28.1 & 28.0 & 27.5 & 28.3 & 28.5 & 28.0 & 27.0 & 28.3 \\
\hline July & 27.3 & 26.9 & 27.7 & 27.7 & 27.9 & 27.2 & 27.5 & 27.9 & 27.6 & 28.3 \\
\hline August & 27.2 & 27.3 & 28.0 & 28.0 & 27.6 & 27.6 & 27.8 & 27.1 & 27.2 & 28.3 \\
\hline September & 27.9 & 27.7 & 28.2 & 28.1 & 27.6 & 28.1 & 27.8 & 27.3 & 27.3 & 27.3 \\
\hline October & 28.6 & 28.3 & 28.5 & 28.5 & 27.9 & 28.4 & 28.0 & 27.9 & 27.9 & 28.2 \\
\hline November & 27.3 & 28.2 & 28.5 & 28.4 & 28.0 & 28.0 & 28.1 & 28.1 & 28.7 & 28.8 \\
\hline December & 28.0 & 28.0 & 28.5 & 28.2 & 28.3 & 28.3 & 28.4 & 28.3 & 29.0 & 28.6 \\
\hline Average & 27.8 & 27.6 & 28.1 & 28.1 & 28.0 & 27.8 & 28.0 & 28.0 & 28.0 & 28.3 \\
\hline
\end{tabular}

Source: Bitung's Maritime Station of Meteorological, Climatology, and Geophysics Agency, 2017

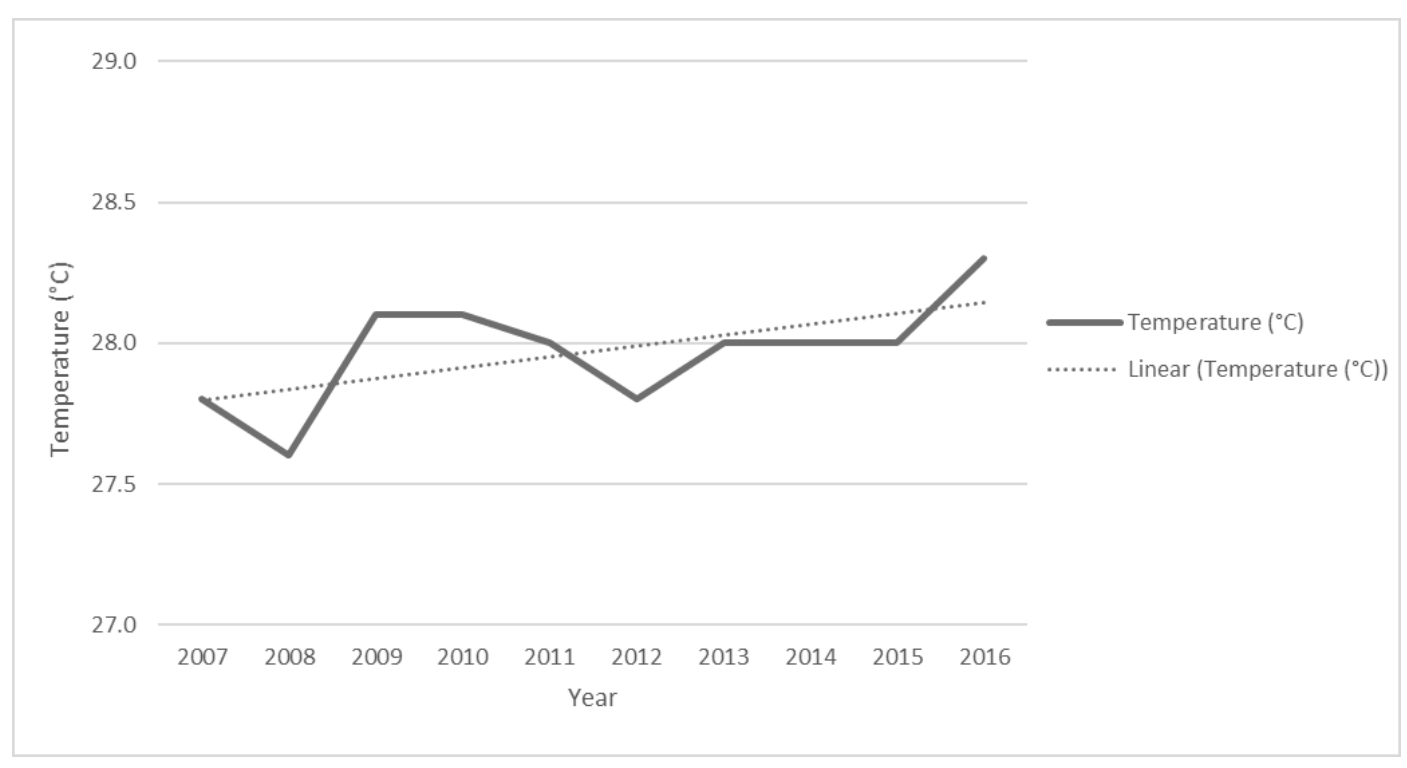

Source: Author's Analysis, 2018

Figure 2. The trend of Annual Average Temperature (2007-2016)

The scoring calculation then converted to the awareness level and found the level of awareness for the two indicators $81.15 \%$ and $79.85 \%$ respectively. This value falls in the range of "quite strong" awareness (see Figure 3). From the two indicators, citizens showed that they are more aware of the irregularity of the season than the increase in temperature. This, perhaps because of the season's irregularity is more physically proven than the increase of temperature as not every household have the tool to measure the temperature change. Moreover, the increase in temperature could be adjusted with the technology such as an air conditioner or fan in every house. 
Table 3. Concern about Climate's Variability

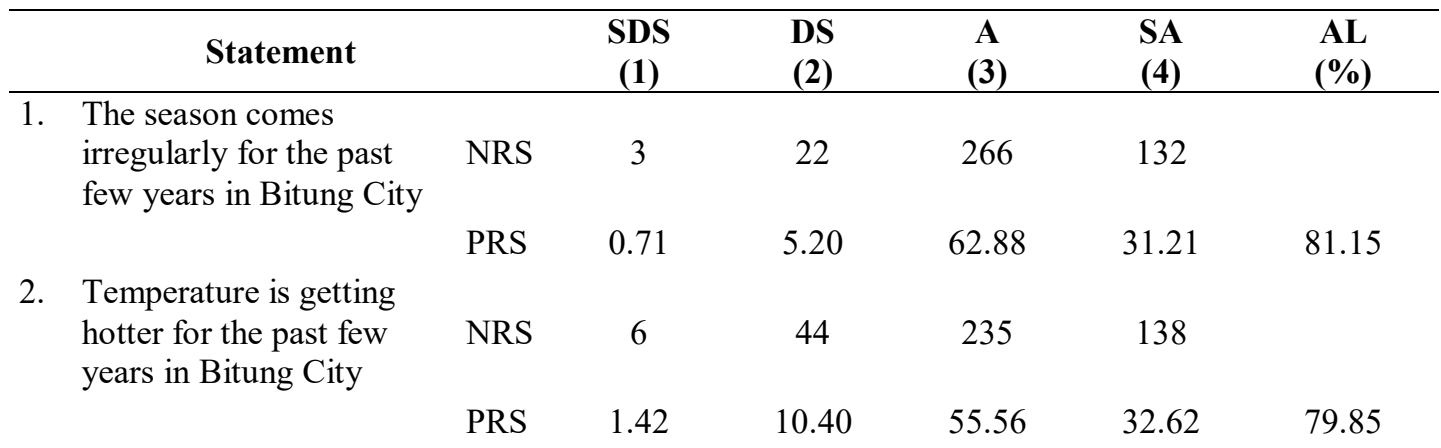

Notes: NRS, PRS, SDS, DS, A, SA, and AL indicate the number of respondents, percentage of respondents, Strongly Disagree, Disagree, Agree, Strongly Agree, Awareness Level Source: Author's Analysis, 2018

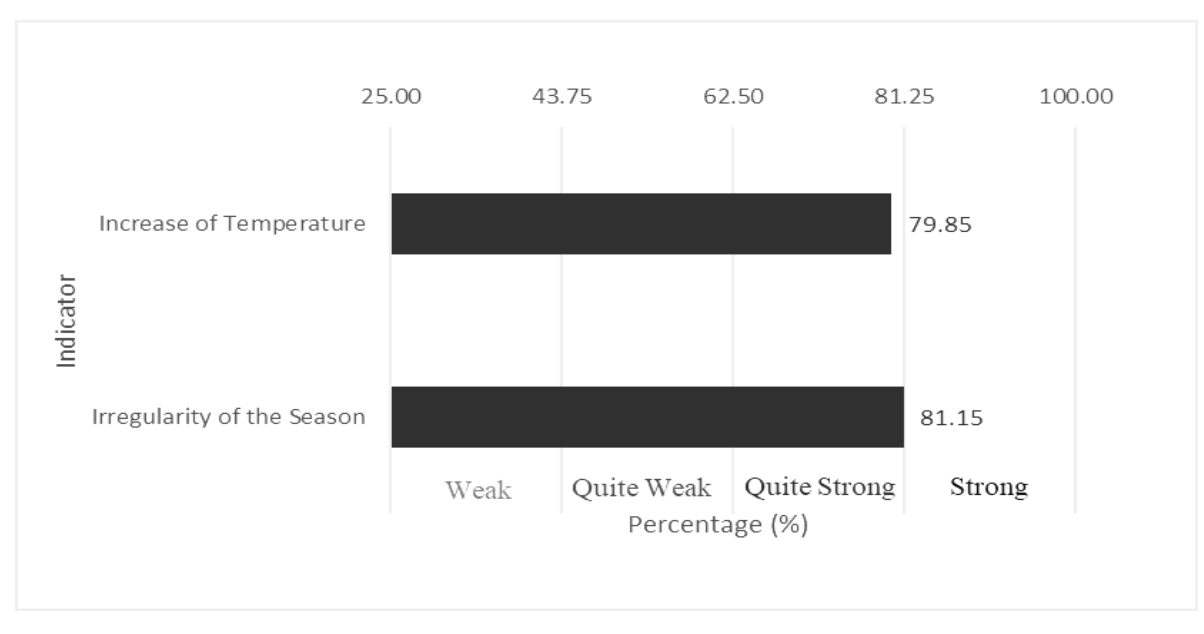

Source: Author's Analysis, 2018

Figure 3. Level of Awareness for Concern about Climate's Variability in Bitung

\section{Concern about the Causes of Climate Change}

This variable assessed the citizens' concern about the causes of climate change which consists of four indicators, i.e., the factory emissions, vehicle emissions, waste heap, and excessive electricity use. Respondents have been asked for their perception of the four indicators abovementioned as the factors that can cause climate change. The result, as can be seen in Table 4 , shows a variability response for every indicator.

There is a $29 \%$ and $58 \%$ of the respondents that had a "strongly agree" and "agree" opinion about factory emissions as the causes of climate change. In addition, $12 \%$ of respondents showed their "disagree" opinion, and only $1 \%$ stated a "strongly disagree" opinion for this indicator. Moreover, for the vehicle emissions indicator, "strongly agree" and "agree" opinions stated by $22 \%$ and $20 \%$ of respondents respectively. $17 \%$ of respondents stated their "disagree" opinion for the vehicle emissions as the causes of climate change and $1 \%$ said that they were "strongly disagree" with this statement. There are $20 \%$ of respondents "strongly agree" that waste heap can cause climate change while $50 \%$ of respondents said, "agree." Consecutively, $25 \%$ and $5 \%$ of the respondent stated that they were "disagree" and "strongly disagree" for this cause. Furthermore, while being asked for the excessive use of electricity as the cause of climate change, $15 \%$ said they "strongly 
agree," and 47\% "agree." A 33\% stated "disagree," and 5\% stated "strongly disagree" opinion for this indicator.

Table 4. Concern about the Causes of Climate Change

\begin{tabular}{|c|c|c|c|c|c|c|c|}
\hline & Statement & & $\begin{array}{c}\text { SDS } \\
\text { (1) }\end{array}$ & $\begin{array}{l}\text { DS } \\
\text { (2) }\end{array}$ & $\begin{array}{c}\text { A } \\
\text { (3) }\end{array}$ & $\begin{array}{l}\text { SA } \\
\text { (4) }\end{array}$ & $\begin{array}{l}\text { AL } \\
(\%)\end{array}$ \\
\hline \multirow[t]{2}{*}{1.} & \multirow{2}{*}{$\begin{array}{l}\text { Factor emissions can cause } \\
\text { climate change }\end{array}$} & NRS & 6 & 50 & 244 & 123 & \\
\hline & & PRS & 1.42 & 11.82 & 57.68 & 29.08 & 78.61 \\
\hline & \multirow{2}{*}{$\begin{array}{l}\text { Vehicle emissions can cause } \\
\text { climate change }\end{array}$} & NRS & 3 & 70 & 257 & 93 & \\
\hline & & PRS & 0.71 & 16.55 & 60.76 & 21.99 & 76.00 \\
\hline & \multirow{2}{*}{$\begin{array}{l}\text { The waste heap can cause } \\
\text { climate change }\end{array}$} & NRS & 20 & 104 & 214 & 85 & \\
\hline & & PRS & 4.73 & 24.59 & 50.59 & 20.09 & 71.51 \\
\hline & \multirow{2}{*}{$\begin{array}{l}\text { Excessive use of electricity can } \\
\text { cause climate change }\end{array}$} & NRS & 23 & 140 & 198 & 62 & \\
\hline & & PRS & 5.44 & 33.10 & 46.81 & 14.66 & 67.67 \\
\hline
\end{tabular}

Notes: NRS, PRS, SDS, DS, A, SA, and AL indicate the number of respondents, percentage of respondents, Strongly Disagree, Disagree, Agree, Strongly Agree, Awareness Level

Source: Author's Analysis, 2018

Of the four indicators, factory emissions received the most robust responses of agreement from the respondents $(87 \%)$ with only $13 \%$ of respondents who stated their disagreement. Similarly, vehicle emissions also believed as the factor that causes climate change by $83 \%$ of respondents and only $17 \%$ of respondents who denied it. There was an increased percentage level in disagreement when waste heap and excessive electricity use stated as the climate change causing factors. Although two-thirds of respondents (70\%) still agree that waste heap can cause climate change, however, there was a significant percentage of respondents (30\%) who disagree. Moreover, a total of $38 \%$ of respondents did not think that excessive use of electricity can cause climate change while the remaining $62 \%$ of respondents showed their agreement.

Based on the conversion of scoring calculations, the level of awareness for this variable is shown in Figure 4 displays that as for the factory emissions indicator, the level of awareness of Bitung's citizens placed the "quite strong" level (78.61\%) as well as vehicle emissions which scored $76 \%$. Moreover, the percentage of waste heap indicator shows the "quite strong" awareness level (71.51\%) and for the excessive electricity use indicator shows the "quite strong" awareness level (67.67\%) as well.

Based on the 2007 IPCC data cited in Holdren (2008), energy supply became the primary source of GHG emission (25.9\%), followed by industry $(19.4 \%)$ and transportation $(13.1 \%)$, while waste contributed $2.8 \%$. Excessive electricity use would be generated by increased demand for electricity which will imply the increase in electricity supply. As the use of fossil fuel in power plant still dominates mainly in developing countries, the extravagant behavior in using electricity will lead to a worse climate change. Emission from factory and vehicle responsible for the $32.5 \%$ of GHG contribution. Together, both factors acclaimed for the main factors responsible for the changing global climate. Although waste only contributed $2.8 \%$ for the GHG emission, however, the behavior in consuming and generating waste by the global citizens that act like there are more than 1.5 planets would increase the possibilities of GHG emissions from the waste (Madumere, 2016). The findings in this variable indicated that the Bitung citizens still had confusion about excessive use of electricity as the causes of climate change although the power plant in Bitung used diesel power plant generated by fossil fuel. However, they were aware of that emissions from factory and vehicle are the contributors to climate change. Furthermore, from the findings, 


\section{The Level of Climate Change Awareness among Citizens of Bitung City, Indonesia}

it can be argued that the citizens had a better understanding of the causes of climate change. This knowledge is expected would lead to the willingness to perform mitigation action in order to reduce GHG emissions.

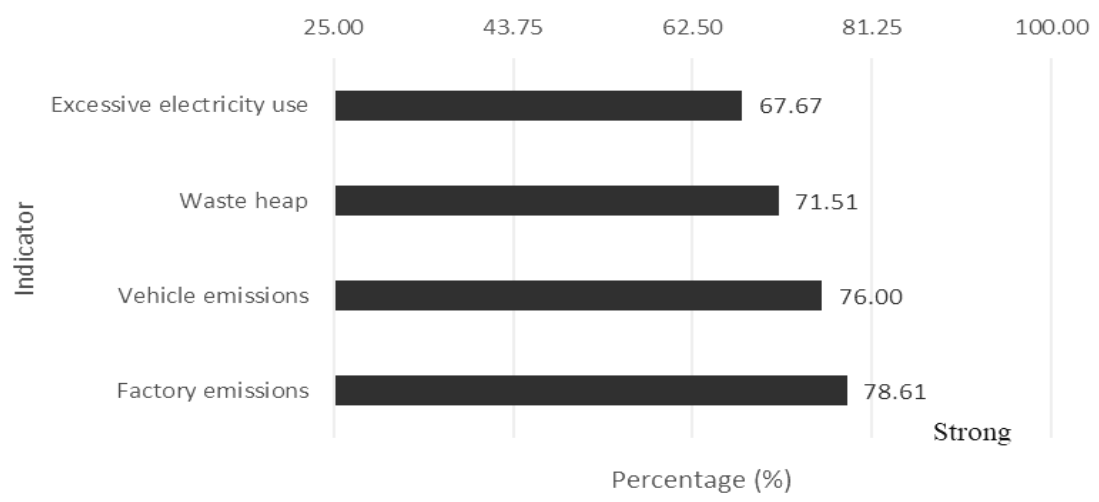

Source: Author's Analysis, 2018

Figure 4. Level of Awareness for Concern about Causes of Climate Change in Bitung

\section{Concern about the Impacts of Climate Change}

The third variable assessed the citizens' concern about the impacts of climate change. The impacts to be assessed are focused on the event of disasters experienced in Indonesia, particularly in Bitung City, i.e., flood, landslides, drought, forest fire, and water scarcity. These disasters are triggered and worsen by the emerging climate change. The respondents have been asked for their opinion about the disasters as the impacts of climate change, and the result is presented in Table 5.

Table 5. Concern about the Impacts of Climate Change

\begin{tabular}{|c|c|c|c|c|c|c|c|}
\hline \multicolumn{3}{|c|}{ Statement } & $\begin{array}{c}\text { SDS } \\
(1)\end{array}$ & $\begin{array}{l}\text { DS } \\
(2)\end{array}$ & $\begin{array}{l}\mathbf{A} \\
\text { (3) }\end{array}$ & $\begin{array}{l}\text { SA } \\
(4)\end{array}$ & $\begin{array}{l}\text { AL } \\
(\%)\end{array}$ \\
\hline \multirow[t]{2}{*}{1.} & \multirow{2}{*}{$\begin{array}{l}\text { Climate change can cause a } \\
\text { flood }\end{array}$} & NRS & 9 & 42 & 257 & 115 & \\
\hline & & PRS & 2.13 & 9.93 & 60.76 & 27.19 & 78.25 \\
\hline \multirow[t]{2}{*}{2.} & \multirow{2}{*}{$\begin{array}{l}\text { Climate change can cause } \\
\text { landslides }\end{array}$} & NRS & 20 & 47 & 246 & 110 & \\
\hline & & PRS & 4.73 & 11.11 & 58.16 & 26.00 & 76.36 \\
\hline \multirow[t]{2}{*}{3} & \multirow{2}{*}{$\begin{array}{l}\text { Climate change can cause } \\
\text { drought }\end{array}$} & NRS & 10 & 62 & 244 & 107 & \\
\hline & & PRS & 2.36 & 14.66 & 57.68 & 25.30 & 76.48 \\
\hline \multirow[t]{2}{*}{4.} & \multirow{2}{*}{$\begin{array}{l}\text { Climate change can cause a } \\
\text { forest fire }\end{array}$} & NRS & 12 & 65 & 236 & 110 & \\
\hline & & PRS & 2.84 & 15.37 & 55.79 & 26.00 & 76.24 \\
\hline \multirow[t]{2}{*}{5.} & \multirow{2}{*}{$\begin{array}{l}\text { Climate change can cause } \\
\text { water scarcity }\end{array}$} & NRS & 7 & 76 & 202 & 138 & \\
\hline & & PRS & 1.65 & 17.97 & 47.75 & 32.62 & 77.84 \\
\hline
\end{tabular}

Notes: NRS, PRS, SDS, DS, A, SA, and AL indicate the number of respondents, percentage of respondents, Strongly Disagree, Disagree, Agree, Strongly Agree, Awareness Level

Source: Author's Analysis, 2018 
For the statement that climate change can cause a flood, $27 \%$ of respondents stated a "strongly agree" opinion, and 61\% said they "agree." A $10 \%$ of respondents said they "disagree" with the statement and $2 \%$ stated their "strongly disagree" opinion. $26 \%$ of respondents said they are "strongly agree" with the statement that climate change can cause landslides while 58\% said, "agree." Another $11 \%$ said they "disagree," and $5 \%$ stated their "strongly disagree" opinion. The statement of that climate change can cause prolonged drought received 25\% "strongly agree" and 58\% "agree" opinion from the respondents. While 15\% stated their "disagree" opinion, another $2 \%$ said they are "strongly disagree" for this statement. For the statement of that forest fire as another impact of climate change received a $26 \%$ "strongly agree" opinion and another $56 \%$ "agree" from the respondents. There are $15 \%$, and $3 \%$ of the respondents stated their "disagree" and "strongly disagree" opinion for this statement respectively. Subsequently, the statement of that water scarcity as the impact of climate change scored $33 \%, 48 \%, 18 \%$, and $1 \%$ of "strongly agree," "agree," "disagree," and "strongly disagree" opinion from the respondents.

From the five indicators, flood received the highest (87.95\%) "agreement" opinion followed by landslides $(84.16 \%)$, drought $(82.98 \%)$, forest fire $(81.80 \%)$, and water scarcity $(80.38 \%)$. Even though the water scarcity had the lowest "agreement" percentage for the climate change impacts, it received the highest score for the "strongly agree on opinion" $(32.62 \%)$ compared with the other impacts. On the contrary, it also received the lowest $(1.65 \%)$ of "strongly disagree" opinion from the respondents.

When the scoring converted to the percentage of awareness level, the results showed a similar "quite strong" awareness level with variability in the percentage, as shown in Figure 5. Although having the same level of awareness, however, the flood had higher percentage level than the other climate change impacts, followed by water scarcity, prolonged drought, landslides, and forest fire. This perhaps caused by the more frequent flood experienced by the citizens for the past few years (Local Disaster Management Board of Bitung City, 2017).

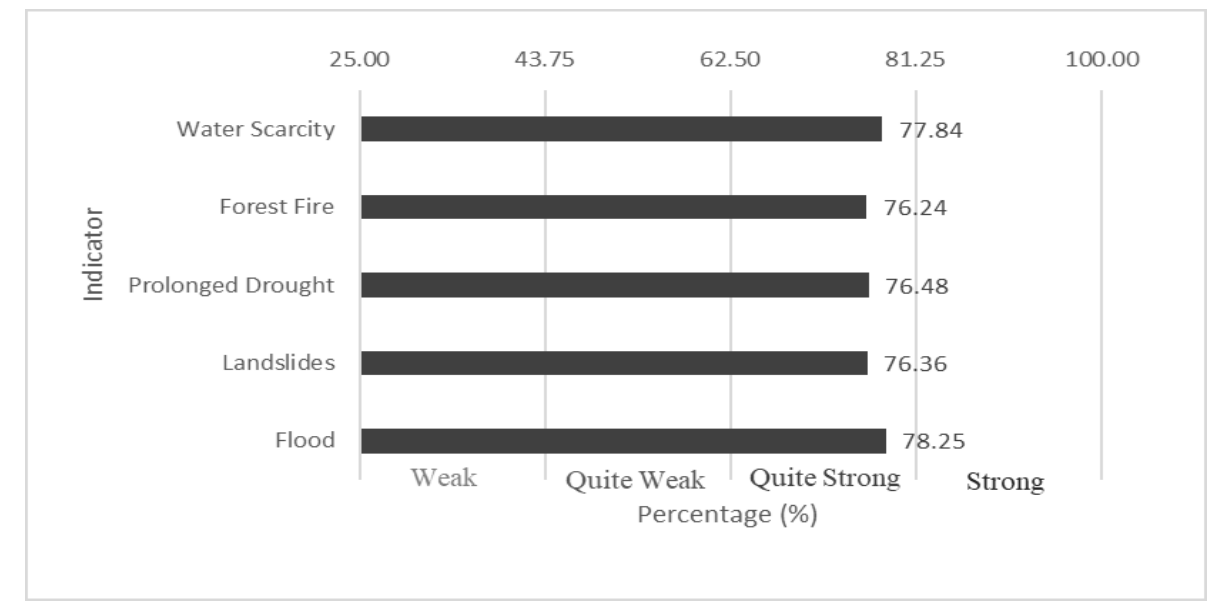

Source: Author's Analysis, 2018

Figure 5. Level of Awareness for Concern about Impacts of Climate Change in Bitung

\section{Conclusion}

Climate change awareness in this research divides into four levels, namely "strong," "quite strong," "quite weak," and "weak." The level is obtained from the scoring conversion of respondent's feedback to the questionnaire based on the Likert scale. The empirical 
research results showed that the Bitung citizens had had a "quite strong" awareness for all variables concerning about the climate's variability, the causes of climate change, and the impacts of climate change. The citizens showed that they have a well-concern about the initial time and duration of the season in Bitung as well as the increase of city temperature, which indicated their better knowledge about climate change.

Moreover, they also exhibited a good knowledge about the causes of climate change by pointing out that factory and vehicle emissions are the highest contributors to climate change within GHG emissions. This could lead to a willingness to perform mitigation action in order to reduce GHG emissions.

Furthermore, the citizens also showed that they had a better understanding of climate change impacts as they can point out the flood and water scarcity on the first place of impacts of climate change in Bitung. The understanding of the impacts of climate change would lead to a positive behavior to support adaptation action (Zamasiya et al., 2017). These findings showed that the awareness level of Bitung citizens was above the average of Indonesian's awareness level, according to the Gallup World Poll. However, there are some indicators that need to be highlighted due to the confusion issue regarding the lower value in awareness percentage, such as excessive electricity use and waste heap as the contributor to climate change. This issue will raise the possibility of counter-productive behavior regarding energy saving and waste reduction.

As the rise of confusion issue as presented above, citizens need to be more aware of the causes and impacts of climate change in order to have better foundation knowledge in performing adaptation and mitigation action. The government could support this within a set of program that enlightenment people and educate them that can integrate the climate change issue to their daily lives (Madumere, 2016). Moreover, climate change, as the global issue, needs to be involved and integrated into the development program led by the government (Vij, Biesbroek, Groot, \& Termeer, 2018). A special task force focusing on the climate change issue needs to be established to address these recommendations. It will work from the planning of adaptation and mitigation strategies, the implementation monitoring until the evaluation process of efforts undertaken to tackle climate change. Furthermore, an effort to establish regulation regarding climate change and its enforcement would be needed by the city government in order to prevent citizens from the impending climate change disasters.

\section{Acknowledgment}

The authors would like to thank the Ministry of Public Works and Housing of Republic Indonesia for the double-degree scholarship and the government and citizens of Bitung City for the support during the research process.

\section{References}

Biggam, J. (2015). Succeeding with Your Master's Dissertation: A Step-by-Step Handbook (3rd ed.). New York: Open University Press.

Bitung's Maritime Station of Meteorological Climatology and Geophysiscs. (2017). Analisis Hujan Ektrem di Kota Bitung, Sulawesi Utara 12 Februari 2017 (Analysis of Extreme Rainfall in Bitung, North Sulawesi 12 February 2017). Bitung. Retrieved from http://www.bmkg.go.id/artikel/?id=f9rt4976402jq0h85908.

Central Board of Statistics of Bitung City. (2015). Bitung City in Figures 2015. Bitung: Central Board of Statistics of Bitung City.

Central Board of Statistics of Bitung City. (2016). Bitung City in Figures 2016. Bitung: Central Board of Statistics of Bitung City.

Chrysolite, Hanny; Reidinar, Juliane; Josefhine, Chitra; Ge, M. (2017). Evaluasi Kemajuan Komitmen Iklim Indonesia (Indonesia's Climate Commitment Progress Evaluation). Retrieved December 18, 2017, from 
http://www.wri-indonesia.org/id/blog/evaluasi-kemajuan-komitmen-iklim-indonesia.

Dale, V. H., Joyce, L. A., McNulty, S., Neilson, R. P., Ayres, M. P., Flannigan, M. D., .. Wotton, B. M. (2001). Climate change and forest disturbances: Climate change can affect forests by altering the frequency, intensity, duration, and timing of fire, drought, introduced species, insect and pathogen outbreaks, hurricanes, windstorms, ice storms, or landslides. BioScience, 51(9), 723-734. doi:10.1641/00063568(2001)051[0723:CCAFD]2.0.CO;2.

Dhokhikah, Y., Trihadiningrum, Y., \& Sunaryo, S. (2015). Community participation in household solid waste reduction in Surabaya, Indonesia. Resources, Conservation and Recycling, 102, 153-162. doi:10.1016/j.resconrec.2015.06.013.

Elrick-Barr, C. E., Smith, T. F., Preston, B. L., Thomsen, D. C., \& Baum, S. (2016). How are coastal households responding to climate change? Environmental Science and Policy, 63, 177-186. doi:10.1016/j.envsci.2016.05.013.

Food And Agriculture Organization of the United Nations. (2011). Food Wastage Footprint \& Climate Change. Retrieved from http://www.fao.org/3/a-bb144e.pdf.

Ghoneem, M. Y. M. (2016). Planning for Climate Change, Why does it Matter? (From Phenomenon to Integrative Action Plan). Procedia - Social and Behavioral Sciences, 216(October 2015), 675-688. doi:10.1016/j.sbspro.2015.12.060

Ghozali, A., Ariyaningsih, Sukmara, R. B., \& Aulia, B. U. (2016). A Comparative Study of Climate Change Mitigation and Adaptation on Flood Management between Ayutthaya City (Thailand) and Samarinda City (Indonesia). Procedia - Social and Behavioral Sciences, 227November 2015), 424-429. doi:10.1016/j.sbspro.2016.06.096.

Hayles, C. S., \& Dean, M. (2015). Social housing tenants, Climate Change and sustainable living: A study of awareness, behaviours and willingness to adapt. Sustainable Cities and Society, 17, 35-45. doi:10.1016/j.scs.2015.03.007.

Holdren, J. P. (2008). Meeting the Climate-Change Challenge. Retrieved from https://www.belfercenter.org/sites/default/files/legacy/files/2008_1-17_NCSE_final.pdf.

Intergovernmental Panel on Climate Change (IPCC). (2007). Climate change 2007: Impacts, adaptation and vulnerability. Contribution of working group II to the fourth assessment report of the intergovernmental panel on climate change. (M. L. Parry, O. F. Canziani, J. P. Palutikof, P. van der Linden, \& C. E. Hanson, Eds.). Cambridge, UK.

Labulu, H., Lisi, F., \& Tuegeh, M. (2015). Analisa Sistem Tenaga Listrik Di Minahasa Dalam Menghindari Padam Total (Electrical System Analysis in Minahasa in Avoiding Total Off). Teknik Elektro dan Komputer, 26-32.

Lee, T. M., Markowitz, E. M., Howe, P. D., Ko, C. Y., \& Leiserowitz, A. A. (2015). Predictors of public climate change awareness and risk perception around the world. Nature Climate Change, 5(11), 1014-1020. doi:10.1038/nclimate2728.

Lieske, D. J., Wade, T., \& Roness, L. A. (2014). Climate change awareness and strategies for communicating the risk of coastal flooding: A Canadian Maritime case example. Estuarine, Coastal and Shelf Science, 140, 83-94. doi:10.1016/j.ecss.2013.04.017.

Local Disaster Management Board of Bitung City. (2017). Potential Disaster of Bitung City. Bitung.

Madumere, N. (2016). Public enlightenment and participation - A major contribution in mitigating climate change. International Journal of Sustainable Built Environment, 6(1), 9-15. doi:10.1016/j.ijsbe.2016.10.003.

Malee, Mario Rinaldi; S., Benu Olfie L.; Wangke, W. M. (2016). Persepsi masyarakat terhadap program pengelolaan sampah secara reduce, reuse, recylce (3R) di Kelurahan Manembo-nembo Tengah Kecamatan Matuari Kota Bitung. Agri-Sosial Ekonomi Unsrat, 12(2A), 225-238.

Malik, N. K. A., Abdullah, S. H., \& Manaf, L. A. (2015). Community Participation on Solid Waste Segregation Through Recycling Programmes in Putrajaya. Procedia Environmental Sciences, 30, 10-14. doi:10.1016/j.proenv.2015.10.002.

Mananoma, Tiny; Tanudjadja, Lambertus; Mulya, H. (2010). Kajian Sistem Manajemen Air Bersih Kota Bitung (Assessment of Clean Water Management System of Bitung City). In PIT HATHI XXVII (pp. 1-11). Surabaya.

Masud, M. M., Azam, M. N., Mohiuddin, M., Banna, H., Akhtar, R., Alam, A. S. A. F., \& Begum, H. (2017). Adaptation barriers and strategies towards climate change: Challenges in the agricultural sector. Journal 


\section{The Level of Climate Change Awareness among Citizens of Bitung City, Indonesia}

of Cleaner Production, 156, 698-706. doi:10.1016/j.jclepro.2017.04.060.

Ministry of Environment and Forestry. (2016). Climate Change Adaptation Policy and Programs in Indonesia. Retrieved from www.apeksi.id.

Patchen, M. (2006). Public Attitudes and Behavior Change: What Shapes Them and How to Influence Them. Social Psychology. PCCRC Outreach Publication 0601. Retrieved from www.purdue.edu/climate.

Public Works Agency of North Sulawesi. (2014). North Sulawesi Spatial Planning 2014-2034. Retrieved from www.http://bappeda.sulutprov.go.id

Rao, V. S. (2011). Public awareness about global warming in Hyberabad, India. San Jose State University.

Singh, A. S., Zwickle, A., Bruskotter, J. T., \& Wilson, R. (2017). The perceived psychological distance of climate change impacts and its influence on support for adaptation policy. Environmental Science and Policy, 73(September 2016), 93-99. doi:10.1016/j.envsci.2017.04.011.

Vij, S., Biesbroek, R., Groot, A., \& Termeer, K. (2018). Changing climate policy paradigms in Bangladesh and Nepal. Environmental Science and Policy, 81(November 2017), 77-85. doi:10.1016/j.envsci.2017.12.010.

Wijaya, A., Chrysolite, H., Ge, M., Wibowo, C. K., Pradana, A., Utami, A. F., \& Austin, K. (2017). How Can Indonesia Achieve Its Climate Change Mitigation Goal? An Analysis of Potential Emissions Reductions From Energy and Land-use Policies. Working Paper. Jakarta, Indonesia: World Resources Institute., (September). doi:10.4155/cmt.13.77.

World Bank. (2011). Vulnerability, risk reduction and adaptation to climate change: Indonesia. Climate Risk and Adaptation Country Profile, 71), 9-12. doi:10.1111/j.1740-9713.2010.00403.x.

Zamasiya, B., Nyikahadzoi, K., \& Mukamuri, B. B. (2017). Factors influencing smallholder farmers' behavioural intention towards adaptation to climate change in transitional climatic zones: A case study of Hwedza District in Zimbabwe. Journal of Environmental Management, 198, 233-239. doi:10.1016/j.jenvman.2017.04.073. 